\title{
Life-Cycle Energy Analysis of a Modular/Off-Site Building School
}

\author{
M.A.Paya-Marin ${ }^{*}$, J.Lim, B.Sengupta \\ School of Planning, Architecture and Civil Engineering, Queen's University Belfast, Belfast, U.K. \\ *Corresponding author: mpaya01@qub.ac.uk
}

Received March 28, 2013; Revised April 23, 2013; Accepted April 26, 2013

\begin{abstract}
This paper is concerned with assessing the building's the energy efficiency and qualities of a modular design for the education industry, in order assess the long economic benefits. The research includes a life-cycle energy and cost analysis of the school building design, predicting the impact on the operational cost of the building as a result of the addition of photovoltaic panels. The paper also includes a comparative study between the ECO Modular Solutions building, and a current standard prefabricated school building, quantifying the savings in $\mathrm{CO}_{2}$ emissions and savings in cost.
\end{abstract}

Keywords: life-cycle energy analysis, energy efficiency, low-energy building, life- cost analysis, modular schools

\section{Introduction}

The reduction of energy building is a concept that recently has gained significant international attention. It can be seen as one of the building sector's initiatives for further reduction of buildings' energy use and overall mitigation of greenhouse gas emissions.

The UK target in carbon emissions is to achieve $80 \%$ reduction by 2050 . The carbon emissions by building industry account more than $45 \%$ of this figure and it has been estimated that $81 \%$ of the buildings occupied in 2050 have already been constructed. The important of the effort in reducing carbon emissions in the building sector is immense and will demand an efficient policy and an improvement in skills of the construction professionals [1]

Life-cycle energy analysis (LCEA) is the process of estimating the environmental impacts linked to a process or final product from the extraction to demolition. In the buildings subject-matter, Life-cycle energy analysis normally has included calculating the apportionment of energy use over time related with two bearings: material and operating effects.

Life-cycle energy analysis is a commonly deployed method for studying a cost-optimal solution or product design. It has also become one of commonly used tools in the design phase of a building.

Design decisions concerning building sustainability have a direct impact in building energy consumption [2].

The main framework of this paper is based on the idea of a low-energy building design, this study provides an optimal combination of renewable energy sources and energy efficiency measures into the building design.

\section{Life-Cycle Energy Analysis Methodology}

Energy is consumed directly or indirectly in all life cycle energy phases, on buildings life energy cycle, there is interaction between embodied energy and operating energy. Reference [3] shows a critical review of five different types of buildings to investigate the impact associated with the choice of building materials, operating energy in these buildings account $90 \%$ of the total effects and far exceeded any differences in embodied energy between the buildings. Therefore, the total energy of these buildings only differs at most by $6 \%$ over a 50 year lifespan.

Reference [4] shows the analysis of 73 case studies in 13 different countries, including commercial and residential buildings, and concluded that operating energy accounted between 80 and $90 \%$ and embodied energy between 10 and $20 \%$ over the life of the buildings

It is determined from these previous studies that operating energy accounts between 80 and $90 \%$, in buildings life cycle energy, embodied energy between 10 and $20 \%$, and demolition has an insignificant share.

This paper is concerned with assessing the building's performance in order to evaluate its energy consumption and identify potential improvements. A modular/off-site building school designed by eco modular solutions [5] was selected to act as case study for this research.

The energy use within the modular building was analysed using IES Virtual Environment (VE) 2012 software. In essence, IES-ve is a commercially available software package, and provides dynamic and comprehensive energy simulation for building.

The analysis is based on real weather conditions, including both solar gains through windows, as well as heat produced by HVAC system.

A 3-dimensional model, developed based on the building, in order to estimates the $\mathrm{CO}_{2}$ emissions based on the type and volume of fuel and electricity consumed by the building. Furthermore, the $\mathrm{CO}_{2}$ emissions associated with the building energy consumption are analysed in order to determine the energy efficiency improvements and, in particular, the effect of solar PV technology. 
A comparison with a standard modular building also has been conducted in order to quantify the $\mathrm{CO}_{2}$ emissions and energy savings.

\section{Standard Building}

A typical modular school in Norther Ireland, U.K. (Figure 1) is used for this comparative, it has $120 \mathrm{~m}^{2}$ plant; suspended timber floor construction, fibre cement board with stipple finish composite panels in external walls, timber truss roof construction. Aluminium powder coated windows, glazed doors and flush external doors, floor, wall and ceiling finishes, and mechanical and electrical installations

The modular units are placed on prepared strip foundations of $600 \mathrm{~mm}$ wide by 300 deep at aprox. $3.0 \mathrm{~m}$ centres and $215 \mathrm{~mm}$ block work piers. The units are bolted together and sealed to provide weather - proof envelope. The units can be readily split and removed off site for resale should the accommodation be no longer requiredvalues meeting the National Calculation Methodology. (External Walls 0.35, Floors 0.25, Roof 0.25, Windows and Doors 2.2) The HVAC system is a standard natural gas boiler having $83 \%$ efficiency.

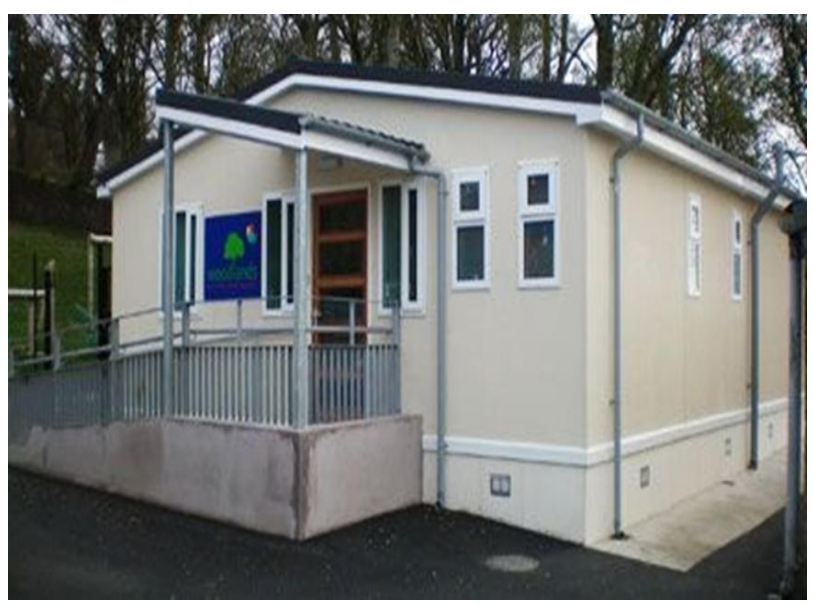

Figure 1. Standard building example

\section{Energy Use}

The energy use within the Standard building was analysed. Table 1 shows the calculation results for the energy use simulation. The energy uses within the building was simulated for a whole year, using real climatic data. According to the simulation results the annual energy consumption for the Standard building was 35179.56KWh. Note that the energy demand depends on school calendar.

\section{Eco Modular Solutions Building}

The design has a $120 \mathrm{~m}_{2}$ open plant, the single storey multifunctional building will be manufactured off-site in modular units and will be transported and offloaded and set in place by crane (Figure 2). The foundations have been designed as screw piles, they do not require concrete and sitting on top is a glulam ring beam. The SIP panel envelope units will be placed on the ring beam. The modular building system allows optimization of the thickness of insulation, minimization of the cold bridges and improvement of the acoustics of the building.

\begin{tabular}{cccc}
\multicolumn{3}{c}{ Table 1. Energy demanded by Standard building } \\
\hline Month & $\begin{array}{c}\text { Energy Required } \\
\text { Heating \& Hot } \\
\text { water system } \\
(\mathrm{kWh})\end{array}$ & $\begin{array}{c}\text { Load for } \\
\text { lighting system } \\
\text { \& equipament } \\
(\mathrm{kWh})\end{array}$ & $\begin{array}{c}\text { Total Energy } \\
\text { demand by } \\
\text { Standard building } \\
(\mathrm{kWh})\end{array}$ \\
\hline January & 3852.30 & 990.00 & 4842.30 \\
February & 4157.32 & 975.00 & 5132.32 \\
March & 3024.54 & 982.00 & 4006.54 \\
April & 2780.69 & 956.00 & 3736.69 \\
May & 1873.33 & 873.00 & 2746.33 \\
June & 400.00 & 553.00 & 953.00 \\
July & 0.00 & 0.00 & 0.00 \\
August & 0.00 & 0.00 & 0.00 \\
September & 359.00 & 540.00 & 899.00 \\
October & 2551.05 & 796.00 & 3347.05 \\
November & 3583.14 & 968.00 & 4551.14 \\
December & 3970.19 & 995.00 & 4965.19 \\
\hline Annual & 26551.56 & 8628.00 & $\mathbf{3 5 1 7 9 . 5 6}$ \\
\hline
\end{tabular}

\begin{tabular}{|c|c|c|}
\hline $\mathrm{CO}_{2}$ emmission for fuel & $\begin{array}{c}\text { Demand } \\
(\mathrm{kWh})\end{array}$ & $\mathrm{Kg} \mathrm{CO}_{2}$ \\
\hline Natural Gas $\left(0.24 \mathrm{kgCO}_{2} / \mathrm{kWh}\right)$ & 26551.56 & 6372.04 \\
\hline Electricity $\left(0.43 \mathrm{kgCO}_{2} / \mathrm{kWh}\right)$ & 8628.00 & 3710.12 \\
\hline Annual $\mathrm{CO}_{2}$ emissions by the system & & 10082.16 \\
\hline 50 years building lifespan $\mathrm{CO}^{2}$ emissi & system & 504108.00 \\
\hline
\end{tabular}

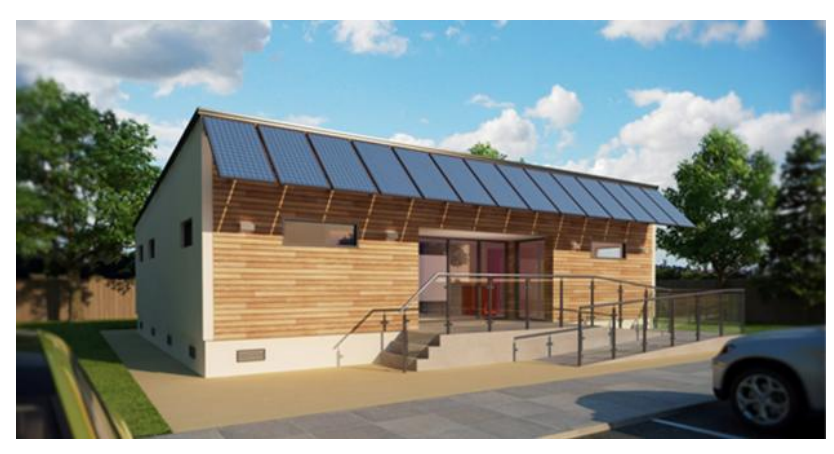

Figure 2. Eco Modular solutions building

\section{Constructions Elements}

External Wall: Polymer modified render system $1,5 \mathrm{~mm}$. Cellulose/fiber cement building board $9 \mathrm{~mm}$. Timber Battens, fixed vertically and drained at bottom $15 \mathrm{~mm} \times 25 \mathrm{~mm}$. Tyvek Breather Membrane, $1 \mathrm{~mm}$, SIP Panel, 11mm OSB, 150mm Insulation, $11 \mathrm{~mm}$ OSB. Timber Battens, fixed vertically to allow for internal services $50 \mathrm{~mm}$ x $25 \mathrm{~mm}$. Vapour Membrane/Airtight barrier $9 \mathrm{~mm}$. Plasterboard 12.5mm. Floor: Timber Battens fixed to joists forming the supporting edge. Vermin fitted to the supporting edge. Rigid insulation $150 \mathrm{~mm}$ to fill remaining space with any small gaps filled with expanding foam Air tight membrane (500 gauge plastic sheet) then fitted to the top surface. Roof: cold roof system with aluminium standing seam cladding fixed to the SIP panel. A membrane is fixed to the SIP panel before linear fixing 
channels are fitted. SIP panels $11 \mathrm{~mm}$ OSB $+128 \mathrm{~mm}$ Insulation $+11 \mathrm{~mm}$ OSB. Foil backed plasterboard layer $12.5 \mathrm{~mm}$. Windows: aluminium System 445SB windows.

\section{HVAC System}

The HVAC system is based on air source heat pump. It produces enough heat for space heating and for domestic hot water. The space heating system is based on radiators layout. The ventilation system uses the concept of decentralized mechanical ventilation with heat recovery in winter time and natural ventilation in summer time. The system is controlled by $\mathrm{CO}_{2}$ sensors. This ventilation concept of the building results in small pressure losses and thus low electricity demand for transporting the air. Moreover, it allows users to control the system better according to their individual.

\section{Lighting}

T5 fluorescent with HF Ballast servicing the open space will have auto-dimming where they are located near sources of natural light. Compact low energy bulbs in the kitchen, office and in the Toilet Block where will have occupancy sensors installed.

\section{Photovoltaic Installation Analysis}

The maximum power produced by a PV installation will be lower than the peak power. The reason for this is because a high level of solar radiation is only achieved in very sunny conditions. The actual solar radiation received will be dependent on other such collector temperature, orientation, over shading and weather conditions.

Figure 3 shows an hourly average solar radiation for representative months of the year for Ireland [6]. The potential power generation of the $14 \mathrm{PV}$ panels, standard size of $1.6 \mathrm{~m} \times 0.8 \mathrm{~m}$ is approximately $3 \mathrm{KW}$.

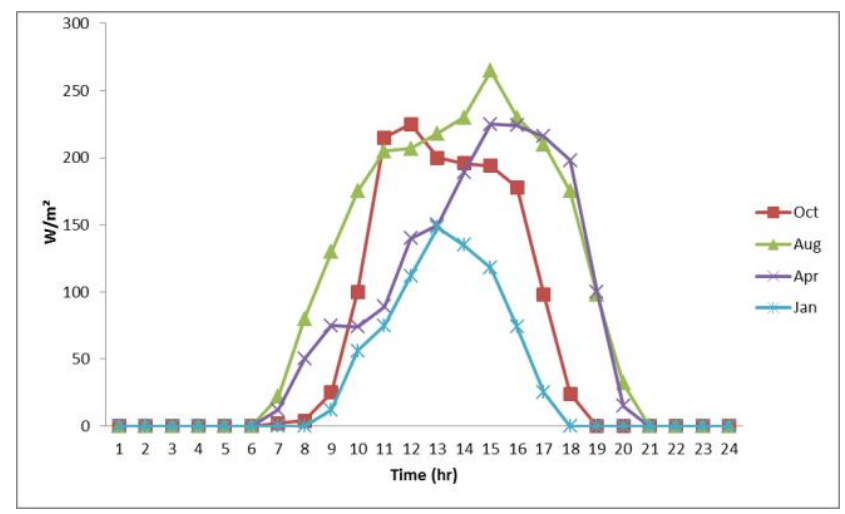

Figure 3. Solar radiation for representative months, Ireland

\section{Energy Use}

The energy use within the case study was analysed using IES-ve software; Table 3 shows the calculation results for the energy use simulation at the buildings. This table shows the simulated energy consumption by the ECO modular solutions building.
Table 3. Energy demanded by Eco building

\begin{tabular}{cccc} 
& \multicolumn{3}{c}{ Table 3. Energy demanded by Eco building } \\
\hline Month & $\begin{array}{c}\text { Energy } \\
\text { consumed by } \\
\text { Eco modular } \\
\text { solutions heating } \\
\text { System }(\mathrm{kWh})\end{array}$ & $\begin{array}{c}\text { Load for } \\
\text { lighting system } \\
\text { by Eco modular } \\
\text { solutions }(\mathrm{kWh})\end{array}$ & $\begin{array}{c}\text { Energy } \\
\text { consumed by Eco } \\
\text { modular } \\
\text { solutions System } \\
(\mathrm{kWh})\end{array}$ \\
\hline January & 1282.81 & 736.00 & 2018.81 \\
February & 1384.39 & 750.00 & 2134.39 \\
March & 1007.17 & 722.00 & 1729.17 \\
April & 925.97 & 660.00 & 1585.97 \\
May & 623.82 & 450.00 & 1073.82 \\
June & 133.20 & 350.00 & 483.20 \\
July & 0.00 & 0.00 & 0.00 \\
August & 0.00 & 0.00 & 0.00 \\
September & 119.55 & 350.00 & 469.55 \\
October & 849.50 & 465.00 & 1314.50 \\
November & 1193.19 & 532.00 & 1725.19 \\
December & 1322.07 & 723.00 & 2045.07 \\
\hline Annual & 8841.67 & 5738.00 & $\mathbf{1 4 5 7 9 . 6 7}$ \\
\hline
\end{tabular}

Table 4. $\mathrm{CO}_{2}$ emissions in $\mathrm{Kg}$ by Eco building

\begin{tabular}{lcc}
\hline $\mathrm{CO}_{2}$ emmission for fuel & $\begin{array}{c}\text { Demand } \\
(\mathrm{kWh})\end{array}$ & $\mathrm{Kg} \mathrm{CO}_{2}$ \\
\hline Electricity $\left(0.43 \mathrm{kgCO}^{2} / \mathrm{kWh}\right)$ & 14579.67 & 6269.26 \\
Annual $\mathrm{CO}_{2}$ emissions by the system & 6269.26 \\
\hline 50 years building lifespan $\mathrm{CO}_{2}$ emissions by the system & 313462.87 \\
\hline
\end{tabular}

\section{Energy Use Comparative}

The energy uses within the two buildings were simulated for a whole year, using real climatic data. According to the simulation results the annual energy consumption for the ECO building was $8675.17 \mathrm{kWh}$ and $35571.56 \mathrm{KWh}$ for the standard building. The potential energy generate by the PV panels, is $16912 \mathrm{KWh}$ per year according with the building location and weather conditions. Energy used comparative between Standard and ECO building is showed on Figure 4. Energy demand depends on school calendar, on summer time, when the building is not operating, the energy produced by the PV panels achieve the maximum grade. The situation gives the ECO building a possibility to purchase energy from the grid when is needed, and feed excess renewable energy back to the grid when the building is not open, in summer time.

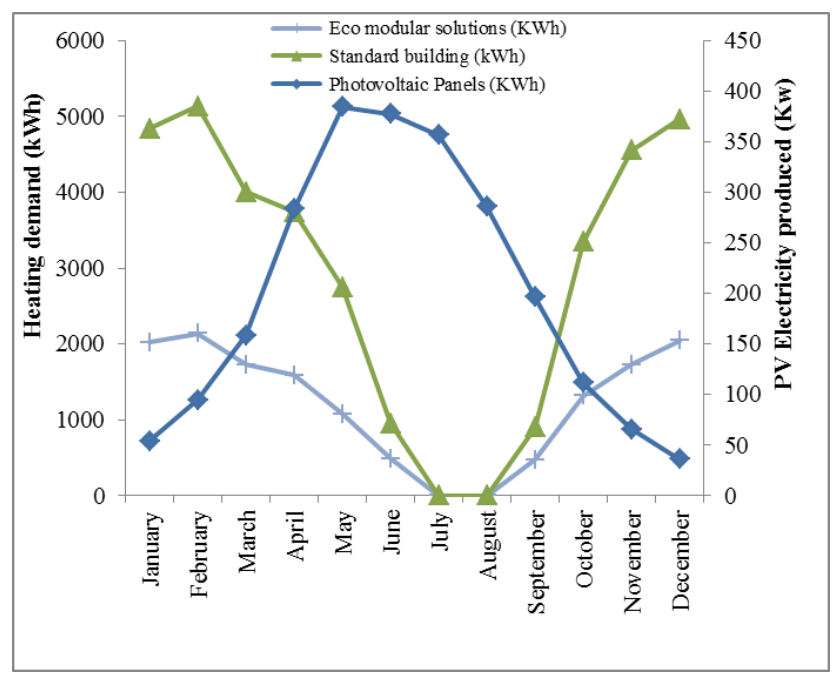

Figure 4. Energy on demand comparative and energy generate by PV panels 


\section{Embodied Energy Analysis}

The energy used during materials manufacturing phase is named embodied energy. This energy is in all the materials used in the building and technical installations, and energy incurred on construction and renovation the building. Energy content of materials refers to the energy used to acquire raw materials (excavation), manufacture and transport to the building site. We used the Hammond method [7] the embodied carbon coefficients were estimated from the typical fuel mix in the relevant UK industries.

The estimated embodied carbon footprint of the building material manufacturing phase and construction process has been represented in Figure 5. According to the results, the embodied carbon for the $\mathrm{ECO}$ building was $8172.45 \mathrm{Kg} \mathrm{CO} 2$ and $20699.02 \mathrm{Kg} \mathrm{CO}_{2}$ for the standard building. The embodied carbon by the ECO building materials and construction phase is $60 \%$ lower than the $\mathrm{CO}_{2}$ footprint by the standard school building.

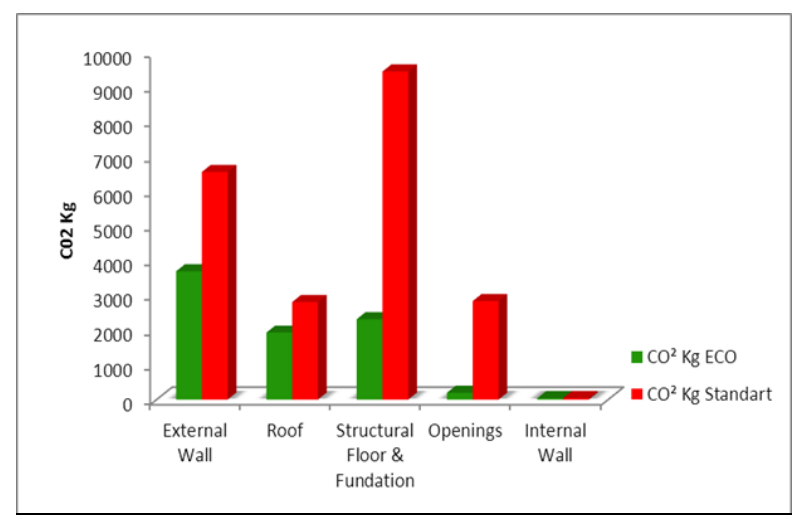

Figure 5. Embodied energy comparative

\section{Life Cycle Cost Analysis}

Buildings are a durable value and consequences have long-term effect in any building decisions, building investors are only concern about the investment cost when they make decisions about building design, construction materials and HVAC systems [8].

In order to avoid this mistake, we must evaluate the building performance in order to make the wright decisions this paper shows an investigation of the costoptimal relation between application energy efficiency measures and renewable energy sources. The tree buildings options were analysed using IES-ve software Table 5 shows the comparative between ECO modular solutions and Standard building.

\begin{tabular}{|c|c|c|c|}
\hline \multicolumn{4}{|c|}{ STANDARD BUILDING } \\
\hline $\begin{array}{c}\text { Heating System } \\
\text { Type: }\end{array}$ & Fuel used & $\begin{array}{c}\text { Demand } \\
(\mathrm{kWh})\end{array}$ & Cost $(£)$ \\
\hline Natural gas & Natural Gas (4.76p/kWh) & 31861.87 & 1516.62 \\
\hline boiler & Electricity $(15.42 \mathrm{p} / \mathrm{kWh})$ & 8628.00 & 1330.44 \\
\hline $\begin{array}{c}\text { (efficiency of } \\
83 \% \text { ) }\end{array}$ & Annual Running cost & & 2847.06 \\
\hline \multicolumn{4}{|c|}{ ECO MODULAR SOLUTIONS } \\
\hline $\begin{array}{c}\text { Heating System } \\
\text { Type: }\end{array}$ & Fuel used & $\begin{array}{l}\text { Demand } \\
(\mathrm{kWh})\end{array}$ & Cost $(£)$ \\
\hline Altherma & Electricity $(15.42 \mathrm{p} / \mathrm{kWh})$ & 14579.67 & 2248.18 \\
\hline system & ROC's Payments* & -2404.61 & -414.07 \\
\hline$(\mathrm{COP}=4,33)$ & Annual Running cost & & 1834.11 \\
\hline
\end{tabular}

\section{Investment Cost (IC)}

The investment cost is the building cost itself including the foundation, the construction materials, the process of producing, transporting and assembling the modules on the building site, the windows and doors, electricity components, water-supply and HVAC system.

\section{Operation and Maintenance Cost $(\mathrm{O} / \mathrm{M})$}

Energy supply systems components, Heat pump system, ventilation installation, lighting, equipment. The annual operation cost is adjusted to its present-value equivalent. Energy cost has been estimate applying the current energy tariff (Table 3). In the Eco modular solution option, the interaction gives the building a possibility to purchase energy from the grid, to feed excess renewable energy back to it, and thus to offset the previous and/or future energy use from the grid. Moreover, it allows elimination of often costly and inefficient onsite storage needed in the case of autonomous.

\section{Conclusion}

The calculated $\mathrm{CO}_{2}$ emissions by operational energy for both buildings were estimated to be around 10.08 and 5.23 tonnes $\mathrm{CO}_{2}$ per year respectively. This translates into a possible $48.11 \%$ reduction in annual household $\mathrm{CO}^{2}$ operating emissions. The results of this analysis show that conventional energy efficiency technologies such as thermal insulation, low-emissivity windows, efficient HVAC systems, and daylighting controls can be used to decrease energy use in new buildings.

The analysis shows that $\mathrm{CO}_{2}$ emissions by buildings depend upon the operating $(85 \%)$ and embodied $(15 \%)$ energy of the buildings

Buildings operating energy, has largest share in life cycle energy distribution, and buildings life cost, reducing it appears to be the most important aspect for the design of buildings which demand less energy throughout their life cycle.

Embodied energy should then be addressed in second instance. In order to reduce operational energy demand of the buildings, passive and active measures such as providing higher insulation on external walls and roof, using gas filled multiple panel windows with low emissivity coatings, ventilation air heat recovery, heat pumps coupled with air heat sources. Building integrated solar photovoltaic panels could be a great inversion to obtain a substantial reduction of $\mathrm{CO}_{2}$ emissions and to achieve an annual payback of the initial investment.

\section{Acknowledgement}

We gratefully acknowledge the financial and technical support of John McGurk, Owner of Eco Modular solutions ltd.

\section{References}

[1] Allwinkle, S. The Chartered Institute of Architectural Technologists Issue 95. 
[2] Schlueter A., Thesseling F., Building information model based energy/exergy performance assessment in early design stages, Automation in Construction, Volume 18, Issue 2, March 2009, p.p 153-163.

[3] Van Oteghem K., Xu 1.,The Life-cycle assessment of a singlestorey retail building in Canada, Building and environmental,.49. pp.212-216, 2012.

[4] Ramesh T, Prakash R, Shukla KK. Life cycle energy analysis of buildings: an overview. Energy Buildings.42, (1), pp.592-600, 2010.

[5] Eco modular solutions, Available online at http://www.ecooffsite.co.uk/.

[6] Sustainable energy authority of Ireland, available online at http://www.seai.ie/Publications/Renewables_Publications/Solar_E nergy/Best_Practice_Guide_for_PV.pdf.

[7] Hammond, G.P. Jones C.I. Embodied energy and carbon in construction materials. Proceedings of the Institution of Civil Engineers - Energy, 161 (2), pp. 87-98, 2008.

[8] Marszal A. J., Life cycle cost analysis of a multi-storey residential Net Zero Energy Building in Denmark, Energy, 36 ,pp.5600-5609, 2001. 